\author{
Magdalena Hawrysz \\ Uniwersytet Zielonogórski
}

\title{
Kategoria Innego jako element dyskursu tożsamościowego w średniopolskich katalogach władców - perspektywa krzyża
}

\begin{abstract}
Język rozumiany jako samoistny byt pozaprzestrzenny to hipostaza i fikcja [...]. Jest on bowiem rezultatem wielowiekowego rozwoju, jest procesem historycznym odbywajacym się w konkretnym miejscu, w konkretnych warunkach i ogarniającym ludzi z konkretnego środowiska.
\end{abstract}

[Doroszewski 1982: 149].

\section{Uwagi metodologiczne}

Współczesna humanistyka, w tym i językoznawstwo, jest obszarem wielkich przemian, czego wyrazistym dowodem jest trans- czy interdyscyplinarność. Ścisłe wyznaczanie granic dziedzin naukowych jest dziś chyba złudne, może nawet szkodliwe, choć tęsknota za czystością metodologiczną jest tu i ówdzie wyrażana. Proces przeobrażeń w zakresie paradygmatów badawczych jest zauważalny również na gruncie historii języka. Jak stwierdza Bogdan Walczak [2012: 109]: „Współczesna historia języka jest [...] subdyscypliną wyraźnie polimetodologiczną". W lingwistyce historycznej (podobnie zresztą jak i we współczesnej) po wielu fundamentalnych osiągnięciach podejścia strukturalistycznego coraz częściej dochodzą do głosu metody pozwalające zobaczyć w języku nie tylko byt abstrakcyjny, ale przede wszystkim narzędzie porozumiewania się konkretnej wspólnoty. Tym samym przedmiotem badania czyni się komunikacyjne aspekty języka oraz różnorodne wymiary życia społeczno-kulturowego, celem zaś opisu jest nie tylko kod, ale i jego użytkownicy, ich system wiedzy, sposoby myślenia o świecie, wyznawane przez nich wartości. Tego rodzaju spojrzenie jest dziś potrzebne, pozwala bowiem uzupełnić obszary w lingwistyce dotąd niezagospodarowane, ale jest także jedną z atrak- 
cyjniejszych form badań historycznych, ponieważ czyni z językoznawstwa dziedzinę par excellence humanistyczną.

Stosunkowo chętnie w obszarze badań nad dawną polszczyzną są podejmowane analizy pozostające $w$ kręgu lingwistyki antropologicznej, dyscypliny akcentującej związki między człowiekiem, językiem i kulturą. Szczególną rolę odgrywa tu teoria językowego obrazu świata, zwłaszcza w wydaniu szkoły lubelskiej ${ }^{1}$. Niniejszy szkic wpisuje się w ten nurt badań, traktuje jednak rekonstrukcje konkretnych wycinków rzeczywistości służebnie wobec celu nadrzędnego, tzn. odtworzenia dyskursu tożsamościowego w Rzeczypospolitej szlacheckiej².

Wyraźnie zauważalny w wielu współczesnych dyscyplinach naukowych zwrot dyskursywny wiąże się - jak można sądzić - z atrakcyjną dla badaczy obserwacją, że rzeczywistość jest wytwarzana w procesach komunikacyjnych, w określonej sytuacji społecznej i na tle określonego kontekstu społecznego [zob. Grzymała-Kazłowska 2004]. Taki sposób oglądu materii językowej zaczyna powoli wkraczać również do badań diachronicznych [zob. np. Siuciak 2011ab; Rejter 2015].

Analiza dyskursu nie wypracowała własnych narzędzi badawczych, w opisach wykorzystuje się instrumentarium już istniejące. W niniejszym opracowaniu sięgnięto po kategorie poznawcze językowego obrazu świata (dalej: JOS) w celu zrekonstruowania obrazu Innego, uznając, że wyobrażenie obcego (podobnie jak tworzenie autostereotypu) jest jednym z fundamentów kształtowania tożsamości zbiorowej. Pierwsze podjęte studia nad wizerunkiem obcego w kontekście rekonstrukcji dyskursu tożsamościowego pozwoliły wyznaczyć trzy perspektywy, w których postrzega się Innego; jest to optyka miecza, korony i krzyża [Hawrysz 2016]. Przedmiotem zainteresowania w niniejszym szkicu jest obraz Innego widziany przez pryzmat krzyża, a więc realizujący religijny (tu: katolicki) punkt widzenia. W kręgu szczegółowych analiz znajdą się zatem portrety innowierczych obywateli Rzeczypospolitej, tzn. Żydów ${ }^{3}$ i osób wyznań poreformacyjnych. Z obserwacji wyłączono muzułmanów, ponieważ w katalogach władców wyznawcy islamu występują jedynie jako najeźdźcy (perspektywa miecza), a religia jest tylko dodatkowym, wspierają-

1 Jako przykład opracowań mieszczących się w tym nurcie warto wymienić książki Doroty Kozaryn [2009], Aleksandry Niewiary [2000, 2010] czy Ewy Woźniak [2007].

2 Zagadnienie to było już podejmowane w kilku artykułach i referatach, zob. np. Hawrysz 2014, 2015. Tam też dokonano opisu podstawowych pojęć i wskazano podstawową literaturę przedmiotu, do czego już nie wraca się w niniejszym opracowaniu.

3 Przyjęto pisownię wielką literą, ponieważ ówcześnie wyznawanie religii mojżeszowej było jednoznaczne z przynależnością do narodu żydowskiego. 
cym elementem ich negatywnej charakterystyki ${ }^{4}$. W analizach nie uwzględniono także pogan, wśród których Polacy szerzyli wiarę katolicką. Decyzja podyktowana jest dwoma faktami - po pierwsze, działalność misyjna ograniczała się wówczas do jednej warstwy społecznej (duchowni), po drugie, aktywność ta (i w konsekwencji obecność pogan na kartach katalogów) jest konsekwencją już ukształtowanej i umocnionej katolickości, staje się więc czynnikiem wzmacniającym funkcję propagandową katalogów, dodatkową ilustracją propagowanego stosunku do niewiernych.

\section{Historiografia - pamięć zbiorowa - wspólnotowa tożsamość}

Materiałem źródłowym opracowania uczyniono teksty powstałe w XVII i XVIII wieku [zob. Źródła] ${ }^{5}$, reprezentujące charakterystyczny dla doby średniopolskiej typ piśmiennictwa historiograficznego, jakim są katalogi władców. Stwierdzenie przydatności tego rodzaju pisarstwa w odtwarzaniu dyskursu tożsamościowego opiera się na przekonaniu, dziś już ocierającym się o truizm, że pamięć zbiorowa jest fundamentem wspólnotowej tożsamości, a zasadniczą rolę w kształtowaniu pamięci odgrywały wówczas (a niemałą odgrywają i dziś) dzieła dotyczące przeszłości.

Zagadnienie pamięci zbiorowej jest niezwykle nośnym problemem współczesnej nauki, głównie socjologii. Temat obrósł nad wyraz obfitą literaturą przedmiotu, by przywołać tylko kamienie milowe, jak pionierskie na tym polu prace Maurice'a Halbwachsa [2008] i fundamentalne na gruncie polskim studia Barbary Szackiej [2006]. Pamięć zbiorowa już w XIX wieku została uznana przez uczonych za najważniejszy składnik tożsamości zbiorowej, dostrzeżono jej formacyjny charakter i moc. Takie myślenie jest reprezentowane i w niniejszym szkicu. Katalogi władców - nośniki pamięci - dostarczały depozytu wiedzy w zakresie tego, co i jak ma być pamiętane. Tym samym można je traktować jako narzędzie społecznej komunikacji nastawione na kształtowanie zbiorowej tożsamości wspólnoty narodowej (w owym czasie ograniczała się ona do stanu szlacheckiego). $\mathrm{Z}$ tej perspektywy można im przypisać funk-

$4 \mathrm{~W}$ analizowanych tekstach nie wspomina się w ogóle tzw. polskich Tatarów.

5 Pierwotnie ekscerpcji podlegały również teksty z wieku XVI, okazało się jednak, że nie ma w nich fragmentów dotyczących Innego innowiercy. Wydaje się, że jest to powodowane dwoma czynnikami: a) formalnotekstowym (utwory XVI-wieczne są bliskie prototypowi gatunku, a więcej uwag o innowiercach pojawia się w tekstach odleglejszych od generycznego centrum; realizacje nieprototypowe pojawiają się od wieku XVII), b) społeczno-kulturowym (chodzi o rosnący w siłę w wyniku działań kontrreformacyjnych katolicyzm oraz przekonanie o roli Rzeczypospolitej jako przedmurza chrześcijaństwa dochodzące szczególnie silnie do głosu w stuleciu XVII). 
cję dydaktyczną (upowszechniały i utrwalały wiedzę o świetnej przeszłości państwa i jego obywateli za pomocą opisu czynów władców), wychowawczą (dostarczały wzorców zachowań) i wynikającą z nich - nadrzędną - funkcję propagandową związaną z projektowaniem tożsamości narodowej.

Jak wspomniano, wizerunek obcego innowiercy stawał się jednym z ważniejszych czynników formacyjnych w Rzeczypospolitej szlacheckiej. Oczywiście stosunek do wyznawców innych religii był różny w zależności od czasu historycznego i rodzaju wyznania, a zależał przede wszystkim od takich czynników, jak umacniająca się kontrreformacja, uznanie Polski za przedmurze chrześcijaństwa oraz wzrost pozycji ekonomicznej Żydów. Czynniki te wpływały na wzmożoną obecność niekatolików na kartach katalogów oraz na ich intencjonalną charakterystykę. Z perspektywy kształtowania tożsamości narodowej nie ma jednak znaczenia rozróżnienie chronologiczne, bez względu bowiem na czas zawsze chodziło o zaprezentowanie Innego jako punktu odniesienia dla samoformowania; to właśnie w konfrontacji z Innym następowało dookreślenie tego, kim się jest.

\section{Sposoby nominacji Innego}

Fundamentem, który determinuje wizerunek Innego, jest oczywiście inna niż katolicka wiara. W katalogach innowierstwo jest konceptualizowane jako: BŁĄD, OSZUSTWO (btędy luterskie i aryjańskie ${ }^{6}$ Pr: 215]; luterańskie batamuctwa [Pr: 215]), CHOROBA (herezyja zarażeni [Pr: 155]) oraz PAKT Z DIABŁEM, bycie we władaniu szatana (czartu zpaszczęki wydrzeć [Pr: 155]; z czartowskich rąk wyrywat [Pr: 258]). Konsekwencją jest opatrywanie go epitetem przeklęte [Pr: 225], nazywanie bezbożnościa [Ko: 294; Pr: 325] lub czarami [O: 113]. Ta perspektywa przesądza zarówno o sposobach nazywania innowierców, jak i o przypisywanych im cechach i zachowaniach.

Katalogi władców przynoszą dwa sposoby nominacji Innego: neutralny i ekspresywny.

W pierwszym kręgu można wyróżnić etnonimy odnoszące się do wyznawców judaizmu: $\dot{Z} y d$ [O: 113], Żydostwo [O: 112], Żydowin [O: 163], Żydówka [Pr: 207], $\dot{Z} y d z i$ [Ko: 170]. W wyekscerpowanym materiale ich łączna liczba użyć wynosi 35 i jest wyraźnie większa od użyć nacechowanych. Nie przesądza to jednak o neutralnym wizerunku Żydów w katalogach, ponieważ ich obraz kształtowany jest przede wszystkim przez opis czynów (o czym niżej). Zupełnie wyjątkowe w kręgu neutralnym są określenia niekatolickich odła-

6 Cytaty podaje się w pisowni uwspółcześnionej. Skróty źródeł zob. s. 48-49. Wszystkie wyróżnienia moje - M.H. 
mów chrześcijaństwa, pojawiają się zaledwie dwa: arianie [Ko: 233], kalwini [Pr: 104]. W odniesieniu do tej grupy wyznawców dominuje nacechowany sposób oznaczania, wydatnie wzmacniający charakterystykę opisową.

Drugi krąg - miana ekspresywne - zawiera nazwy spolaryzowane wedle religii. Wyłącznie do Żydów odnoszą się: haramza żydowska [Ko: 169] 'tłum, gawiedź, tłuszcza' [SXVII i XVIII], jadowity naród [Pr: 222] 'nikczemny, okrutny, krzywdzący, zabijający' [SXVI], jaszczurczy naród [Pr: 219] 'lud zły, podstępny, przebiegły' [SXVII i XVIII], śmierdziuchowie [Pr: 219]. Wyrażenia te - pogardliwe i ujawniające najwyższą niechęć - przynoszą supozycję o nieprzyjaznym, może nawet agresywnym zachowaniu Żydów, ich przewrotności i chytrości; wskazują też na stereotypowo przypisywaną im cechę kulturową, tzn. zapach (czosnku, cebuli jako składników kuchni żydowskiej).

Wśród nacechowanych nazw niekatolickich odłamów chrześcijaństwa można wskazać trzy kategorie. Pierwszą z nich tworzą nazwy pozornie neutralne: dysydenci [Ko: 293], heretycy [Ko: 209], heretyctwo [Pr: 240], kacerstwo luterskie [Pr: 227], odszczepieńcy [Pr: 258], odszczepieństwo [Pr: 179], luterska i kalwińska sekta [Pr: 293], sekta luterska [Pr: 293], sekty heretyckie [Pr: 273]. Etymologicznie nawiązują one do pojęć nie zgadzać się, wybierać, odstapić, podązać za kimś (na podstawie SWO). Jednak na znaczeniu i nacechowaniu tych wyrazów zaważył hegemoniczny dyskurs katolicki. Katolicka ortodoksja zawęziła pojęcia dysydenta, heretyka, odszczepieńca, sekty do kręgu osób pozostających w dogmatycznym błędzie, tym samym wyrazy zaczęły nabierać negatywnego zabarwienia. To nacechowanie podkreślają współwystępujące epitety wartościujące: sekta brzydka [Pr: 155] oraz opisowo-wartościujące, nawiązujące do sfery sacrum: sekta przeklęta begowinów heretyków [Pr: 155], Luter niezbożny wzniecat przeklęta sektę [Pr: 199], a także deprecjonujące konstrukcje zaimkowe: sekta jakaś [Ko: 113]. Szczególny status mają w tym kręgu leksemy oznaczające wyznawców prawosławia: schizmatycy [Pr: 258], schizmatyczka [Pr: 196]. One również, choć prymarnie neutralne, wyrażają niechętny stosunek do wyznawców Kościoła wschodniego. Można to odczytać z fragmentu, w którym mowa o Helenie Moskiewskiej, żonie Aleksandra Jagiellończyka, królowej Polski, która nie została koronowana ze względu na wyznanie. Religia prawosławna rzadko jest wspominana na kartach katalogów, a stopień nieprzychylności do niej jest mniejszy w porównaniu z innymi wyznaniami. Być może wpływ na to miał czas, jaki upłynął od schizmy wschodniej, być może również unia brzeska.

Druga kategoria nazw nacechowanych to miana wyrażające nie tylko negatywny stosunek, ale także wskazujące na jego przyczynę, tzn. odstąpienie od (prawdziwej) wiary: batwochwalce książęcia kijowskiego [Pr: 146], bezboż- 
nik [Pr: 325], bluźniercy Boga [Pr: 222], pogaństwo [Pr: 111], świętokradce [Pr: 288]. Tu w sposób jawny określa się niekatolików jako żyjących bez Boga lub wyznających fałszywego boga, profanów uwłaczających świętościom.

Trzecia wreszcie kategoria to określenia, które prócz wyrażania funkcji ekspresywnej suponują agresję, bezlitosność, zło: okrutnik [Ko: 233], zgraja ludzi [Pr: 325], złoczyńcy [Pr: 326]. Ujawniany w nich negatywny rys jednoznacznie kwalifikuje obcych innowierców.

Można uznać, że wszystkie nazwy (ze względu na kontekst występowania również te uznane tu za neutralne) pełnią funkcję etykietek, a więc określeń oceniających. Stopień ich upowszechnienia był znaczny, czego dowodzą poświadczenia leksykograficzne, a użycie w popularnym gatunku piśmiennictwa utrwalało je i sankcjonowało ich stosowanie, a tym samym przyczyniało się do ugruntowania postaw wobec Innego widzianego w perspektywie krzyża.

\section{Cechy i atrybuty Innego}

Zasygnalizowane przez sposoby nominacji cechy innowierców i stosunek do nich zyskują potwierdzenie i rozwinięcie w charakterystyce dokonywanej przez przypisywane im cechy i atrybuty wyrażane w postaci przymiotnikowych ewaluatywów lub rzeczownikowych nazw wartości negatywnych, obecnych jako stały element kolokacji nazw obcego. W odniesieniu do Żydów pojawiają się prywata, swoboda, wolność (w znaczeniu 'nieskrępowanie, swawola'), złość: żydowska prywata [O: 112], Żyd na wierzchu ma swoje swobode [O: 113], Żyd wolny [O: 113], zlość żydowska [O: 113]. Pozostałym innowiercom przypisuje się furię, złość, swawolę: pożar furyi dysydentów [Ko: 293], zawzięta złość [Ko: 294], swawola niestychana [Ko: 295]. W istocie w wypadku obu grup pojawiają się te same cechy. Można więc uznać, że były to właściwości przypisywane stereotypowo, mające na celu nie tyle charakterystykę Innego, ile intencjonalne budowanie jego negatywnego wizerunku i wzbudzanie do niego niechęci.

Innowiercom przypisuje się też egocentryzm i chciwość. Zyskuje to np. odbicie w krytycznym opisie chełpienia się przez Żydów bogactwem: Aleć teraz z żydostwa już, mości panowie, / W ojczyźnie naszej miłej prawi pótpankowie. / Jeśliże pan arendarz, to już para koni [O: 112], oraz narzekaniu na opanowanie przez nich poboru podatków i wszechobecność w miastach: $C \nmid a$, miasta i miasteczka pod mościwym panem [O: 112]. Wskazana w katalogach swoboda może być utożsamiana z samowolą i niesubordynacją reprezentantów pozakatolickich wyznań oraz ich bezkarnością (nie znają kary [O: 113]). Szczególne znaczenie w ich charakterystyce ma wściekłość, wedle katalogowych 
opisów skutkująca niepohamowanymi zniszczeniami, zwłaszcza w katolickiej sferze sacrum (por. niżej). Wszystkie cechy zyskują uogólnienie w postaci przypisywanej Innemu złości, co można interpretować jako wszelkie zło, z którym kojarzono niekatolików.

Dopełnieniem charakterystyki atrybutywnej jest obrazek przywołujący niecodzienne zdarzenie, które miało miejsce w żydowskim miasteczku, późniejszej dzielnicy Krakowa: Na Kazimierzu u Żydów cielec urodził się o siedmiu nogach, ze dwiema głowami, jedna tam była, gdzie ogon, a ogon na grzbiecie. Było to paresagium przyszłego nieszczęścia, bo Turcy w roku 1498 siedemdziesiąt tysięcy wpadli [Ko: 170]. W przywołanym fragmencie dochodzi do głosu powszechna wówczas wiara w znaki zapowiadające ważne zdarzenia. W przekonaniu dziejopisów wiele zajść było poprzedzonych „wieszczym opowiedzeniem", co miało być dowodem na ingerencję boskiej opatrzności. Znamienne w tym wypadku jest, że incydent zwiastujący tragiczne historie to przyrodnicze kuriozum. Można przypuszczać, że chciano związać wizerunek Innego z wynaturzeniami i anomaliami, a tym samym wzbudzić czy spotęgować niechęć do niego, a nawet strach przed nim.

\section{Czyny Innego}

Pełnię charakterystyki Innego przynoszą fragmenty relacjonujące jego zachowania. Wszystkie, znów w odniesieniu do każdej niekatolickiej grupy wyznaniowej, pozwalają mówić o obcym jako krzywdzicielu. Językowa konceptualizacja innowierców w tym obszarze daje się ująć w trzy zasadnicze wizerunki.

Pierwszy z nich to obraz ŚWIĘTOKRADCY. Żydom zarzuca się kupowanie sakramentów (W Sochaczowie uboga od Żydów najęta, / Sakrament im przedała [O: 173]; Żyd sakramenta kupuje [O: 112]) oraz postponowanie chrześcijaństwa ( $W$ ten czas bluźnit Żydowin chrześcijańska wiare [O: 163]). Natomiast chrześcijan niekatolików obciąża bezczeszczenie Najświętszego Sakramentu (Przenajświętszy Sakrament [...] wyrzucić chcieli [Ko: 295]) oraz profanowanie innych katolickich świętości, takich jak: świątynie, klasztory, kolegia jezuickie, święte obrazy, krucyfiksy, np.:

[...] dla wielkich nawałności od kalwinów, którą na ten czas Klasztory Gdańskie cierpiały. [Pr: 104]

Przyszło było dwóch arianów do tego obrazu, z których jeden dobytym mieczem uderzył kilka razy w twarz Najświętszej Panny, mówiąc: doświadczę jeżeli prawdziwą wiarą cuda się tu stają. [Ko: 223] 
Obrazy Niepokalanego Poczęcia Panny Maryi Świętego Franciszka Ksawiera i inszych świętych wziąwszy, z naśmiewiskiem i bluźnierstwem na ulice wyniósłszy, na ziemie rzucili, a potym ogień dokoła podnieciwszy, wzorem poganów bałwochwalców [...] przezeń skakali, mówiąc, a bardziej wyziarniając te słowa: Brońże się teraz Dzieweczko. Vivat Maryja etc. [Pr: 325]

Obszernych opisów relacjonujących potężne zniszczenia dokonywane przez rozjuszonych innowierców znajduje się w katalogach niemało. Ich stylistyczną dominantą (zauważalną u różnych autorów) jest amplifikacja i enumeracja, por.:

[...] z alabardami, siekierami, szpadami i z inszym tak wiele orężem poszedszy ku jezuickiemu kolegium, tam okna powybijali, w kumorach albo celach jezuickich drzwi, sprzęty domowe porąbali, pieniędzy, co było na potrzeby kolegium, zabrali, wielo obrazów [...] sprośnie sprofanowali, niektóre kawałki podarli, niektóre porąbali, poprzestrzelali, nogami starli, zdeptali. [Ko: 294-295] ${ }^{7}$

[...] wielka zgraja ludzi z muszkietami, siekierami, szpadami poszła do Kolegium Ojców Jezuitów i tam pod pretekstem szkołaka swego wszystko rumowali [...] stołki, piece, okna porąbali, powybijali, a czego strach i wspomnieć, Obrazom Ukrzyżowanego Pana Jezusa, Najświętszej Panny i inszych świętych nie przepuścili, nogi krucyfiksowi poodcinali, ołtarze dwa [...] na sztuki porozcinali, inszych tak wielo obrazów częścią porozdzielali, częścią poprzebijali, poprzecinali, poprzestrzelali, obstawiających ludzi świeckich czy duchownych ranili. O okrucieństwo, którego by się najwięksi poganie nie ważyli. [Pr: 325]

Drugi typ wizerunku wyłaniający się na podstawie zachowań innowierców zamyka się w kategorii KRZYWDZICIELE KATOLIKÓW. Żydom zarzuca się trucie wody (Żydowska prywata, // Tak twierdza kronikarze, wodę nam potruła [O: 112]), pozostałym zaś lżenie, dręczenie, pobicia i nastawianie na życie (niebezpieczeństw, urągania, krzywd od heretyków [Pr: 278]; Zakonników

7 Identyczny niemal fragment znajduje się w Fortecy monarchów Piotra Hiacynta Pruszcza: $Z$ halabardami, siekierami, szpadami i z inszym tak wiele orężem poszedtszy Jezuickiemu Kościołowi i wybiwszy drzwi do kolegium tam okna powybijali, w komorach albo celach jezuickich drzwi, sprzęty domowe porąbali, pieniędzy co byto na potrzeby kolegium zabrali, wielo Obrazów [...] sprofanowali, niektóre na kawatki podarli, [...] porabali, postrzelali, nogami starli, deptali [Pr: 325]. Zagadnienie zależności treściowej katalogów władców warte jest osobnych rozważań. 
pobili, poranili, nie wprzód kończąc swawola niestychana, póki co do obelgi zupetnej i wykonania złości należało, nie uczynili [Pr: 327]; uciski, frasunki, potwarzy cierpiała od heretyków [Pr: 225]; utrapienie od heretyków [Pr: 225]).

Silnie eksponowanym rysem Innego jest uznanie go za MORDERCE. Gwoli ścisłości należy dodać, że w wypadku chrześcijan mowa wyłącznie o cudzoziemcach:

[...] od bałwochwalce książęcia kijowskiego srogiemi mękami byli trapieni i pozabijani, szczęśliwie korony męczeńskiej dostąpili. [Pr: 146]

Co widząc niezbożny król czeski, od szatana w złość ubrany, tegoż kapłana heretykom jak najprędzej zabić kazał. [Pr: 155]

Kapłana niewinnego wywlekli, po ulicach i przecznicach włóczyli, bijąc, tłukąc tak, aż mózg z głowy od srogiego bicia wypadał, a na ostatek mieczem wpół przebity, swego żywota (broniąc wiary katolickiej) dokończył roku 1341. [Pr: 155]

Natomiast Żydzi w Polsce powszechnie posądzani byli o dzieciobójstwo. To zresztą bardzo trwały w historii narodowej mit. W Fortecy monarchów Piotra Hiacynta Pruszcza, specyficznym katalogu, w którym portrety władców są zaledwie pretekstem do prezentowania sylwetek świętych, błogosławionych i męczenników, znajdują się liczne fragmenty, w których przypomina się niektóre tylko [Pr: 221] rzekome zbrodnie żydowskie. Prawdopodobieństwa przydaje się im przez zastosowanie strategii uwiarygodnienia, czemu służyć ma cytowanie źródel, wśród których są dokumenty sądowe (księgi wójtowskie [Pr: 221]) i dzieła literackie (Myczyński in suo speculo [Pr: 220-221]), oraz wskazywanie konkretnych dat i zeznań świadków przywoływanych z nazwiska, nierzadko wyposażonych w atrybut władzy kościelnej (np. Ex Commissione Bernardini Maciejowski, Episcopi Cracov. Anno ut supra, die 8 Januarii [Pr: 220-221]). W oświadczeniach tych Żydzi jawią się jako niemiłosierni i srodzy okrutnicy, wytaczający niewinną krew z każdej najmniejszej żyłki, zabijający dzieciątka po dokonaniu rytuału i bezczeszczący zwłoki, np.:

Roku 1648 w miasteczku Iwaniskach Żydzi przeklęci dziecię chrześcijańskie uchwyciwszy, wielkie nad nim niemiłosierdzie mieli, bo go srodze spilkami, igłami i żelazkami ostrymi zakłuli i krew z niego wytoczyli, poty je, aby się dziurki kłute pozamykały, w wosku rozpuszczonym gorącym umoczywszy, za miasto wyrzucili, które chrześcijanie znalazłszy, tamże w kościele pochowali. 
Byli ci przeklętnicy pozywani na trybunał, ale iniustitiati uszli, lecz ich Pan Bóg tego roku sam przez Kozaki na Ukrainie justycyjował i krwie się ich niemowiątek, czego i tam dosyć, pomścił [...] Testes Patres Bernardini cum Patribus Discalceatis Carmelitis. [Pr: 221-222]

\section{Podsumowanie}

Tak scharakteryzowany Inny staje się na kartach katalogów (i w świadomości społecznej czytelników) obcym, najczęściej - wrogiem. Kreowanie skrajnie negatywnego wizerunku musiało rodzić nieprzychylny stosunek do niekatolików i chęć czy raczej konieczność walki z nimi. W samych katalogach pokazuje się rozmaite sposoby rozprawiania się z innowiercami:

a) od biblijnie uzasadnionych prób nawracania:

Heretyków od błędów kazaniem swym, rozmową, pisaniem wielu ksiąg uczonych, odwodzil, a do uznania prawdy nawiódł. [Pr: 226]

Ewangelią świętą tak Żydom, jako i heretykom żarliwie przepowiadal. [Pr: 238]

[...] wielu heretyków i schizmatyków do wiary prawdziwej nawrócil. [Pr: 240]

Wojewodziną ruską uporną bardzo w schizmie, do jedności Kościoła przywiódł, także wielu nowokrzczeńców, Tatar, Żydów i ich mistrzów Chrystusowi Panu pozyskal. [Pr: 240]

b) przez deprecjonowanie ich nauki i otwartą walkę z nią:

[...] potężnie luterskie błędy gromil. [Pr: 229]

Będąc jeszcze w młodym wieku przeciwko nauce luterskiej wiersze pisal, księgi ich palił i inszym do palenia tychże powodem był. [Pr: 229]

[...] błędy luterskie, aryjańskie, kalwińskie gromiąc i niszcząc, utwierdzał, ale też i dysputacyje z heretykami przy obecności królewskiej, żarliwe czynił, na których wielkie zgromadzenia różnego stanu ludzi miewał. [Pr: 241] 
[...] śmiele się oparł heretykom i ich sektę brzydką ganil, psowal i potępiał. [Pr: 155]

Był wielce nabożnym i niespracowanym a żarliwym w opowiadaniu słowa Bożego i wielkim wykorzenicielem heretyków. [Pr: 163]

c) aż do wygnania z państwa:

Tam najprzód aryjanom, których się wiele w Polszcze zagęściło było, precz posłać kazano, we trzy lata dobra sprzedawszy, pod ucięciem głowy. [Ko: 249]

Wszystkie niemal (łaskawe nieba) w niego wlały

Cnoty; widzieć w nim było pomnożenie chwały

Gorliwe Bożej, kiedy przez publikowany

Edykt wywołał z swego państwa aryjany. [M: 50]

d) czy rozwiązań ostatecznych - wcale nierzadkiego zabijania:

Budek powiedział wszytkim na swoim kazaniu

Dziecięcia niewielkiego o zamordowaniu.

A tak wszytko pospólstwo barzo zasmuceni,

Bili, siekli Żydostwo, będąc zajuszeni. [O: 124]

A Żydów tamże kilka na rynku spalono.

Prawym sposobem łotrom za to nagrodzono. [O: 173]

Za tego króla [Zygmunta I - M.H.] Żyd śmiał o swej wierze dysputować, ale będąc przekonany od dominikana spalony w rynku krakowskim. Tego Żyda wierząc nauce Malchrowa, rajczyna krakowska, Żydówką została, i ta spalona na rynku. [Pr: 206-207]

Za panowania jego [Kazimierza Wielkiego - M.H.] nastała sekta jakaś, że ludzie z Węgier przyszedszy, po Polsce chodzili w pół się obnażywszy, biczowali się, tak otrocy, jako i białegłowy, ale ich wygładzono. [Ko: 113]

Obacz, jak Bóg matki swojej najświętszej honoru przestrzega! Jak jej prześladowców [arian - M.H.] karze zgubą życia doczesnego prędką, za która i wieczna utrata następuje. [Ko: 233] 
[...] [dysydentom - M.H.] z dziesięcią inszemi mieszczanami głowy ucięto, także aby piąciu z tych ręce wprzód poucinano a to na teatrum publicznym, umyślnie wystawionym. Ciała zaś osobliwie Karwizy rzeźnika poćwiartowawszy i innych, jako oto Szulca Hassta, Gutborta spalić publicznie rozkazano. Burgrabiego z urzędu swego Gerharda, Cymermana z radziectwa złożywszy, na więzienie osądzono. [Pr: 328]

Warto zwrócić uwagę, że stosunek do innowierców był jednym z kryteriów oceny władców Polski. Szanowano i wychwalano tych, którzy byli wobec niekatolików nieprzejednanie stanowczy, jak np. Jan Olbracht, który wygnawszy Żydów, wedle autora katalogu znamienita rzecz uczynit [Ko: 169]. Podobna postawa u Ludwika Węgierskiego, wzmocniona wyniszczeniem heretyków, zyskała mu pod piórem Pruszcza miano pana nabożnego [Pr: 154]. Natomiast nieumiejący sobie poradzić z konfliktami między innowiercami a katolikami, jak Władysław IV, nazywani są najnieszczęśliwszymi [Ko: 209]. Bezlitosna pryncypialność wobec innowierców nie tylko przynosiła chwałę samemu panującemu, ale także zapewniała pomyślność całemu państwu, czego dowód przywołuje Pruszcz:

Wiktorii tej przyczyną być może, że się król [Jan Kazimierz - M.H.] żadnemi nie dał nakłonić suplikami ani medyjacyjami, żeby dekret przeciw aryjanom uczyniony miał był kiedy odmienić, ale im odpowiedział, gdy mu się groźbą przykrzyli podczas procesyi Bożego Ciała: Lex imperat, non disputat. Jeżeli rewokować nie będziecie, precz wędrujcie z Polskiej. [Pr: 291]

Podsumowując rozważania na temat sposobów postępowania z niekatolikami, Augustyn Kołudzki stwierdza w Tronie ojczystym: Wiele sposobów do zachowania ojczyzny wynaleziono [Ko: 249].

Jak więc widać, katalogi władców dobrze dokumentują postępującą katolicyzację państwa i sankcjonowanie niechętnej postawy wobec niekatolików. Ten proces sprawił, że istotnym składnikiem polskiej tożsamości stało się wyznanie rzymskokatolickie i w pełni uzasadniona stała się użyta w Tronie ojczystym Pruszcza nazwa Katolickie Królestwo Polskie [Pr: 324].

\section{Spis skrótów}

Ko - Kołudzki 1707.

M - Minasowicz 1775. 
O - Obodziński 1640.

Pr- Pruszcz 1737.

SXVII i XVIII - Elektroniczny słownik języka polskiego XVII i XVIIII wieku.

SWO - Sobol, red. 1996.

\section{Bibliografia}

\section{Źródta}

Kołudzki Augustyn (1707), Tron ojczysty abo Pałac wieczności w krótkim zebraniu monarchów, książą i królów polskich, Poznań, http://jbc.bj.uj.edu.pl/dlibra/docmetadata $\mathrm{id}=230627 \&$ from $=\&$ dirids $=1 \&$ ver_id $=\& \mathrm{lp}=1 \& \mathrm{QI}=$, [dostęp: $17 \mathrm{kwietnia}$ 2016].

Minasowicz Józef Epifani (1755), Tron ojczysty, albo życia książat i królów polskich $z$ dziejopisów ojczystych krótko zebrane, rytmem domowym przez J.E.M. określone, w: tegoż, Zbiór rytmów polskich, t. 1, cz. 2, Warszawa, s. 3-60, https:// polona.pl/item/11568156/6, [dostęp: 17 kwietnia 2016].

Obodziński Aleksander (1640), Pandora monarchów polskich, Kraków, http://books. google.pl/books?id=LI1KAAAAcAAJ\&printsec=frontcover\&hl=pl\&source= gbs_ge_summary_r\&cad $=0 \# \mathrm{v}=$ onepage\&q\&f=false, [dostęp: 17 kwietnia 2016].

Pruszcz Piotr Hiacynt (1737), Forteca monarchów, Kraków, http://www.sbc.org.pl/ dlibra/doccontent?id=3834, [dostęp: 17 kwietnia 2016].

\section{Literatura}

Doroszewski Witold (1982), Język, myślenie, działanie, PWN, Warszawa.

Dubisz Stanisław (2010), Historia języka polskiego - „wczoraj, dziś i jutro”, „LingVaria", nr 2, s. 46-51.

Elektroniczny słownik języka polskiego XVII i XVIIII wieku (2016?), http://xvii-wiek. ijp-pan.krakow.pl/pan_klient, [dostęp: 17 kwietnia 2016].

Grzymała-Kazłowska Aleksandra (2004), Socjologicznie zorientowana analiza dyskursu na tle współczesnych badań nad dyskursem, „Kultura i Społeczeństwo”, nr 1, s. 13-34.

Halbwachs Maurice (2008), Społeczne ramy pamięci, PWN, Warszawa.

Hawrysz Magdalena (2014), Kształtowanie narodowej wspólnoty w świetle XVI-wiecznego piśmiennictwa historiograficznego. Rekonesans, „Acta Universitatis Lodziensis. Folia Linguistica", z. 48, s. 21-31.

Hawrysz Magdalena (2015), Mitologizacja przeszłości w katalogach monarchów z okresu I Rzeczpospolitej, czyli o konstruowaniu tożsamości narodowej, w: Mito- 
logizacja kultury w polskiej i iberyjskiej twórczości artystycznej, red. Wojciech Charchalis, Bogdan Trocha, Uniwersytet Zielonogórski, Zielona Góra, s. 187-197. Hawrysz Magdalena (2016), Obrazy obcego w dawnych katalogach władców. Mity i stereotypy (wstęp do badań), w: Mitologizacja człowieka w kulturze i literaturze iberyjskiej i polskiej, red. Wojciech Charchalis, Bogdan Trocha, Uniwersytet Zielonogórski, Zielona Góra, s. 229-238.

Kozaryn Dorota (2009), Językowy obraz faz ludzkiego życia w utworach Mikołaja Reja, Wydawnictwo Naukowe Uniwersytetu Szczecińskiego, Szczecin.

Niewiara Aleksandra (2000), Wyobrażenia o narodach w pamiętnikach i dziennikach z XVI-XIX wieku, Wydawnictwo Uniwersytetu Śląskiego, Katowice.

Niewiara Aleksandra (2003), Schematy ideologiczne w obrazie Żyda w polskiej literaturze pamiętnikarskiej XVI-XIX w., w: Żydzi w literaturze. Materiaty XII Konferencji Pracowników Naukowych i Studentów, red. Anna Szawerna-Dyrszka, Maciej Tramer, Gnome, Katowice, s. 192-209.

Niewiara Aleksandra (2010), Ksztalty polskiej tożsamości. Potoczny dyskurs narodowy $w$ perspektywie etnolingwistycznej (XVI-XX w.), Wydawnictwo Uniwersytetu Śląskiego, Katowice.

Rejter Artur (2015), Romans barokowy - analiza dyskursologiczna wobec granic gatunku. Na przykładzie twórczości Hieronima Morsztyna, w: Gatunki mowy i ich ewolucja, t. 5: Gatunek a granice, Wydawnictwo Uniwersytetu Śląskiego, Katowice, s. 199-209.

Siuciak Mirosława (2011a), Przejawy dyskursu publicznego w dawnych tekstach prawnych, „Język Polski”, z. 1, s. 50-57.

Siuciak Mirosława (2011b), Średniowieczny dyskurs prawny-czyli o początkach stylu urzędowego, w: Odmiany stylowe polszczyzny - dawniej i dziś, red. Urszula Sokólska, Wydawnictwo Uniwersytetu w Białymstoku, Białystok, s. 285-298.

Sobol Elżbieta, red. (1996), Stownik wyrazów obcych, PWN, Warszawa.

Szacka Barbara (2006), Czas przeszły, pamięć, mit, Wydawnictwo Naukowe „Scholar”, Warszawa.

Tazbir Janusz (1973), Stosunek do obcych w dobie baroku, w: Swojskość i cudzoziemszczyzna $w$ dziejach kultury polskiej, red. Zofia Stefanowska, PWN, Warszawa, s. $80-112$.

Walczak Bogdan (2012), Badania w zakresie historii języka polskiego (próba syntezy), w: Językoznawstwo w Polsce. Kierunki badań i perspektywy rozwoju. Materiaty z sesji jubileuszowej Komitetu Językoznawstwa PAN, red. Maciej Grochowski, Bel Studio, Warszawa, s. 99-111.

Woźniak Ewa (2007), Ofiary i krzywdziciele. Studium postaci w przedtrydenckim piśmiennictwie pasyjnym. Analiza językoznawcza, Wydawnictwo Uniwersytetu Łódzkiego, Łódź. 
Magdalena Hawrysz

The category of an Alien as an element of the identity discourse in the MiddlePolish catalogs of rulers - the perspective of cross

This sketch concerns the notions of groups that were considered aliens by the old Poles. Methodologically the work remains in the circle of ethnolinguistic research. The analysis uses the tools developed by the theory of linguistic image of the world. Material has been excerpted from 4 catalogs of rulers created in the period from the seventeenth to the eighteenth century. In the observed catalogs, there are three points of view, from the perspective of which the alien is categorized; these are the optics of a sword, cross, crown. The reconstruction of the infidels' image in the article is carried out in the context of the functions this category plays in the era of shaping and preservation of national identity in a multi-ethnic and multi-religious country.

Keywords: US (BELONGING TO US)/THEM (ALIEN) opposition; identity discourse; catalogs of rulers; national identity; The First Republic of Poland; Jews; infidels.

dr hab. Magdalena Hawrysz - profesorka w Zakładzie Historii i Pragmatyki Języka Polskiego w Instytucie Filologii Polskiej na Uniwersytecie Zielonogórskim; zainteresowania naukowe: dzieje polszczyzny (szczególnie okresu średniopolskiego) w aspekcie komunikacyjnym i kulturowym, dawny i współczesny język artystyczny, genologia lingwistyczna, lingwistyka antropologiczna. 